\title{
Large enterprises of Ukraine, sustainable development and social responsibility: transparency in times of crisis
}

\author{
Vlastimil Vicen $^{*}$ \\ Eva Ruzinska** \\ Andrii Yevstakberych ${ }^{* * *}$
}

Received: 2021-02-24

Accepted: 2021-04-23

DOI: http:/ / doi.org/ 10.46489/ lbsh.2021-1-1-2

Abstract. After the Revolution of Dignity in Ukraine, the crisis conditions have produced challenges in the work of large enterprises and reduced attention to social responsibility. This work aims to identify bottlenecks in the communicative activity of large enterprises on social responsibility. Based on a literature review, we have established a theoretical link between social responsibility, efficiency and transparency. We formulated hypotheses about the connection between enterprise leadership and transparency of social responsibility. To discover the transparency of big business in a crisis, we used the original simple method, which helps us assess the availability and adequacy of information on social responsibility. Using it, we analysed the websites of leading Ukrainian companies in the post-crisis period. According to the study results, we partially confirmed the hypothesis of a higher level of transparency provided by enterprises that are revenue leaders. The obtained results can be helpful for public authorities to develop a national strategy of sustainable development and managers to improve the representation of achievements in the field of social responsibility.

Keywords: sustainability, big business, communications, non-financial reporting, corporate social responsibility

\footnotetext{
* Vlastimil Vicen, DSc, Professor, Vice-Rector for Security and Defense, School of Economics and Management of Public Administration in Bratislava, Furdekova 3240/16, 85104 Bratislava, Slovakia, ORCID: https://orcid.org/0000-0002-13365549

** Eva Ruzinska, PhD, Associate Professor, academic worker, Department of Economy, Institute of Technology and Business in České Budějovice, Faculty of Corporate Strategy, Okružní 517/10, 37001 České Budějovice, Czech Republic, ORCID: https://orcid.org/0000-0003-2554-3012

*** Andrii Yevstakhevych, PhD, lecturer, Department of Business Economics and Information Technology, Lviv university of business and law, Kulparkivska, 99, 79021 Lviv, Ukraine, e-mail: yevstakhevych10@meta.ua, ORCID: https://orcid.org/0000-0003-1058-5359 (corresponding author)
} 


\section{INTRODUCTION}

In the search for new ways of economic and social progress, the concept of sustainable development has gained worldwide recognition. This concept requires the restructuring of socio-economic systems to preserve and increase the economic, human and natural potential of states, taking into account the interests of future generations (Aras, G., \& Crowther, D., 2009). The principle of sustainable development poses new challenges to governments and enterprises (Raco, M. 2005). In particular, it manifests itself in the form of a requirement to conduct business based on social responsibility. The breakdown of old profit-oriented business models, which has been brewing for decades, took the form of a global movement in economically developed countries at the beginning of the 21 st century (Halisçelik, E., \& Soytas, M. A. 2019). This movement reflected a change in worldviews, the humanisation of social relations and approaches to doing business.

Large enterprises of Ukraine need new management decisions in social responsibility due to the imperfection of state mechanisms for sustainable development, poorly developed business culture, lack of scientific, educational, informational support for implementing socially responsible activities (Lipych et al., 2018). Due to detachment from global trends in the development of socially-oriented entrepreneurship, domestic managers are often using outdated notions of social responsibility (Vasyltsiv, T., Lupak, R., \& Rudkovsky, O., 2019). Managers often present social responsibility as a kind of charity, inexpedient and harmful activity for the company in anticipation of the next wave of socioeconomic crisis (Kolohoida, O., Lukach, I., \& Poiedynok, V., 2017). Changing the conservative policy of Ukrainian enterprises in social responsibility will mean approaching the exemplary business practices of developed countries. Such practice will allow the implementation of a new model of the national economy, in which the highest priority is not profit but national well-being and sustainable development.

As we observed, crisis conditions after the Revolution of Dignity in Ukraine caused numerous difficulties in the functioning of large enterprises. The crisis has affected the transparency of social responsibility management as a result of its decay. In this article, we tried to identify some bottlenecks in the communicative activity of large enterprises on social responsibility.

\section{1. Literature Review}

We have observed many scientific papers where the authors discussed sustainable development, transparency and social responsibility of business. Let us describe the most important articles that influenced this work.

Kolk, A., \& van Tulder, R. (2010) emphasised the crucial role of large enterprises in achieving sustainable development through the prism of social responsibility. Lee, M., \& Kohler, J. (2010) based on non-financial reports of medical companies, investigated the response to the crisis that arose due to limited access to drugs. This article proves the importance of transparency for competition, social responsibility, and companies' transformation in crisis conditions. Pejić Bach, M., Ante Omazić, M., \& Zoroja, J. (2015) analysed the transparency of social responsibility of banks based on the development of their websites. Researchers have noted a downward trend in the transparency of subsidiaries of multinational banks in less developed countries. Bhullar, M. (2019) empirically established the link between sustainable development and corporate social responsibility goals and stressed the importance of disseminating knowledge in this area among different groups.

Park, H., \& Ha, M. (2020) investigated the relationship between social responsibility and transparency of Korean companies. Researchers stressed that transparency is one of the foundations of social responsibility. This study confirmed the direct impact of social responsibility on transparency. Nair, R. et al. (2019) focused on the transparency and quality of information the company provides to investors. In this context, the researchers stressed the debate over the appropriateness of non-financial disclosure. Nair, $R$. et al. emphasise the lack of significant links between CSR disclosure and financial transparency. Hendijani Zadeh, M. (2020) found a clear link 
between the transparency of the company's environmental and social reporting and the level of payments to investors. The scientist stressed the importance of this connection in the light of high information asymmetry. Muñoz Pasadas, R., \& Tirado Valencia, P. (2014), based on data from Spanish companies, clarified the relationship between responsibility, corporate governance and transparency.

Baraibar-Diez, E., \& Luna Sotorrío, L. (2018), in their study, pointed out that transparency mediates the transformation of the results of social responsibility measures into the company's reputation. Kang, J., \& Hustvedt, G. (2014) emphasised the connection between transparency, social responsibility and consumer trust in the company. Their empirical study proved the lasting impact of the transparency of non-financial reporting on consumers' intentions to purchase the company's products. Dehghani Soltani, M., Shiri, A., Nesari, T., Raoufi, M. (2018) proved the impact of transparency and social responsibility on brand sustainability and business efficiency. Mora Mayoral, M. J., \& Martínez Martínez, F. R. (2018) described possible directions for developing corporate social responsibility strategy, taking into account the principle of long-term sustainability.

Watts, S. (2015) considered the organisational, informational and cultural factors of corporate transparency in social responsibility. His paper links social responsibility reporting to organisational transparency. Tejedo Romero, F., Ferraz Esteves Araujo, \& Oaquim F. (2018) noted the importance of disclosing information about the company's human capital, which is evidence of internal social responsibility.

Most researchers take into account reports on social responsibility, but this method is not applicable in the realities of Ukraine. In Ukraine, the relevant reporting has not become so widespread that we can consider it a proper basis for research. The outlined situation requires clarification of the theoretical foundations and methods for a practical and straightforward assessment of large enterprises' transparency of social responsibility in a crisis.

\section{2. Theoretical basics of social responsibility and transparency of large enterprises in Ukraine}

Social responsibility is a global trend to which Ukrainian enterprises are gradually joining. Relevant initiatives are inherent primarily in large enterprises (Kolk, A., \& van Tulder, R., 2010). We can explain it by the availability of significant financial and material, and labour resources, some of which managers can allocate to address social responsibility. In addition, large enterprises mainly have their brand, image, i.e. intangible assets, the value of which depends on attracting investment and expanding the range of loyal consumers (Dehghani Soltani, M., Shiri, A., Nesari, T., Raoufi, M., 2018). So, let us take a closer look at the content and features of social responsibility and the importance of transparency.

Social responsibility is a synthetic category, has long been developed and supplemented with new elements. At the present stage, the UN and governments support social responsibility at the international level. At the transnational level, this concept is promoted by large enterprises, recognising it as one of the keys to sustainable economic development (Pejić Bach, M., Ante Omazić, M., \& Zoroja, J., 2015). In Ukraine, the concept of social responsibility has acquired unique regional shapes. To some extent, it distorted due to the crisis in the economy and society. As a result, in the absence of a systemic public policy (Mostenska, T., \& Bilan, Y., 2015), this gave rise to discrete social responsibility measures and reduced the transparency of communications. Thus, we recognise two main problems of social responsibility of large Ukrainian enterprises: a) implementing nonsystemic charitable measures; b) building an opaque system of social responsibility.

In the theoretical dimension, understanding the concept of social responsibility is still developing. Numerous attempts of large domestic enterprises to adopt foreign practices into domestic realities confirms the importance of this concept. Given the lack of theoretical and methodological support, state and market control, CSR reduces to a particular minimum set, which involves compliance with the state's requirements, 
investors, and rare charity events (Lee, M., \& Kohler, J., 2010).

Social responsibility belongs to the sphere of strategic management and is a component of corporate strategy (Hendijani Zadeh, M., 2020) and, in most cases, is initiated from the outside (Lee, M., \& Kohler, J., 2010). The exception is a charity (Vasyltsiv, T., Lupak, R., \& Rudkovsky, O., 2019), which does not require transparency.

The social responsibility of large enterprises in Ukraine is voluntary, as long as it does not concern the legally regulated aspects. Because of this, it is rather challenging to assess the quality of social responsibility or compare the levels of social responsibility of individual enterprises. However, we can detect transparency in the management of social responsibility of large enterprises, which is of great importance in the exit from the crisis. Transparency can be a demonstration of the attention to the financial and social aspects of the crisis. We consider transparency to be one of the markers that testify to the existence and effectiveness of social responsibility management.

Leading companies traditionally spread the model of business behaviour in the environment. Depending on the model and depth of integration of the concept of social responsibility into corporate strategy (Hendijani Zadeh, M., 2020; Park, H., \& Ha, M., 2020; Muñoz Pasadas, R., \& Tirado Valencia, P., 2014), we can assess the level of transparency of social responsibility depending on the profit or revenue leadership.

Based on theoretical research, we formulated the following research question:

$\mathrm{RQ}_{1}$ : Do leading companies sufficiently ensure the transparency of corporate social responsibility?

Within this question, we considered two hypotheses:

$\mathrm{H}_{1}$ : If social responsibility depends on the amount of profit, the group of profit leaders should have a higher level of transparency of social responsibility.

$\mathrm{H}_{2}$ : If social responsibility depends on the amount of income, the group of income leaders should have a higher level of transparency of social responsibility.

\section{METHODS}

To analyse the transparency of social responsibility of large enterprises in the postcrisis period, we used the following method.

Using previously accumulated materials, we took into account the data from 2016. This year was marked by a gradual recovery of business after the crisis of 2014-2015. Analysis of the transparency of communicative activity of large enterprises this year will allow us to determine the extent of their participation in the process of achieving sustainable development goals in crisis conditions.

According to the rating of 200 largest companies of Ukraine in 2016, the five most profitable companies in 2016 included NJSC Naftogaz of Ukraine, PJSC PivdGZK, PJSC Naftogazvydobuvannya, PJSC Zaporizhstal, SE Ukrainian Sea Ports Authority. On the other hand, the top enterprises in terms of revenue include NJSC Naftogaz of Ukraine, SC Energorynok, PJSC Ukrgasvydobuvannya, PJSC ArcelorMittal Kryvyi Rih, LLC ATBmarket. To create a comparison base, we rejected NJSC Naftogaz of Ukraine and supplemented the list of PJSC NorthGZK by profit and LLC Kernel trade and LLC Tedis Ukraine by revenue. We formed groups of leading companies I (profit leaders) and II (revenue leaders).

We limited ourselves to the study of ten companies, which, given their leadership position, are obliged to demonstrate a high level of transparency of social responsibility.

To assess the level of transparency of corporate social responsibility, we have developed a method that evaluates a set of binary indicators $\mathrm{xn}$ (they can take values 0 or $1)$, grouped into theoretical groups.

I. Transparency: x1 - the presence of a report on social responsibility in free access on the Internet; x2 - availability of information about social responsibility on the website; $x 3$ availability of contacts for more detailed information on social responsibility.

II. Consistency and completeness: $\mathrm{x} 4$ compliance of the report with one of the international standards of non-financial reporting; $x 5$ - the presence of a comparison of results with previous reporting periods; $\mathrm{x} 6$ compliance of the social responsibility 
management system with the Principles of the UN Global Compact.

According to the given list, we assessed the level of social responsibility (SR) as the sum of social responsibility indicators.

We collected the data by analysing the official websites of these companies during 2018. The proposed method has certain limitations, which we will clarify in part of the discussion. However, collecting empirical data by processing enterprises' websites is a typical method (Pejić Bach, M., Ante Omazić, M., \& Zoroja, J., 2015) with several advantages: low cost, reduced subjectivity, reduced data collection time. We supplemented the analysis with data on the general index of transparency of the enterprises studied.

\section{RESULTS}

Systematic and transparency of social responsibility are its principles, as defined in international standards. One of the essential international standards of social responsibility is the UN Global Compact. The GC includes ten principles, grouped into four groups: human rights, labour relations, the environment and anti-corruption. Ukraine has a Global Compact Network - the official representative of the UN Global Compact. As of 2018, 9531 participating companies from 162 countries were registered in the global network, and 47121 public reports were submitted. There are 22 registered participants in Ukraine, of which 9 are public organisations, three universities, four small and medium enterprises, four business companies and two business associations. According to the search results on the main page of the UN Global Compact, we identify 60 participants from Ukraine, of which 18 were companies (Our Participants, 2018, May 16).

The desire to join the company to the Global Compact can be a factor in the transformation of business processes, management models and mechanisms, strategic and operational activities of the company to adapt to the requirements of the principles of GC and contribute to achieving the Sustainable Development Goals. At the same time, the presence of a relatively small number of Ukrainian enterprises in the network indicates a lack of significant interest. Thus, it is possible to assume that as a global standard of social responsibility, the UN Global Compact serves as a theoretical guideline for companies that have decided to embark on the path of social responsibility.

The study showed an insufficient level of communicative activity of large enterprises. The results were presented in Table 1.

Table 1 The results of the survey of the level of social responsibility of the leading enterprises of Ukraine

\begin{tabular}{|l|l|l|l|}
\hline Name of Company & Revenue, UAH billion & Profit, UAH million & SR \\
\hline \multicolumn{2}{|c|}{ Group I } & 5903,59 & 0 \\
\hline PJSC PivdGZK & 14,61 & 5412,15 & 3 \\
\hline PJSC Naftogazvydobuvannya & 9,20 & 4690,08 & 3 \\
\hline PJSC Zaporizhstal & 33,16 & 3854,37 & 0 \\
\hline SE Ukrainian Sea Ports Authority & 7,30 & 3613,10 & 3 \\
\hline PJSC NorthGZK & 15,11 & 1283,49 & 0 \\
\hline \multicolumn{2}{|c|}{ Group II } & 2704,12 & 6 \\
\hline SC Energorynok & 131,02 & 1605,43 & 3 \\
\hline PJSC ArcelorMittal Kryvyi Rih & 52,96 & 185,33 & 3 \\
\hline LLC ATB-market & 48,38 & $-1224,42$ & 1 \\
\hline LLC Kernel trade & 42,61 & & \\
\hline LLC Tedis Ukraine & 42,42 & \\
\hline
\end{tabular}

Source: Own research 
Based on the study results, we assume partial confirmation of the second hypothesis because of the higher average SR points. We can reveal the partiality of the proof as follows.

Only one group II company, PJSC ArcelorMittal Kryvyi Rih, posted on the website generalised information on social responsibility principles, ongoing projects, and a GRI report on social responsibility. There is no data on social responsibility on SC Energorynok (Group II), SE Ukrainian Sea Ports Authority and PJSC PivdGZK (Group I) sites.

The enterprises that scored 3 points did not receive points according to the indicators from the second theoretical group (consistency and completeness). The submitted reports are not comparable. These reports commonly do not take into account standards, and there is no comparison of indicators with other periods. Also, there is no evidence on companies' websites or reports about compliance with the UN Global Compact Principles. LLC Tedis
Ukraine scored one point due to the availability of information about social responsibility on the website. The obtained results are generally consistent with the data of the transparency rating and complement it (Zinchenko A., Reznik N., \& Saprykina M. (2018).

\section{DISCUSSION}

Our study showed that data on social responsibility are moderately entirely $(\mathrm{SR}=3)$ disclosed by companies that prepare nonfinancial reports. For the most part, in times of crisis, the transparency of social responsibility of large enterprises is questionable. Available data are declarative, and companies provide them in the form of fragmentary information messages. This approach may indicate the absence of a comprehensive strategy for social responsibility in a crisis.

Among the non-financial reports for previous periods, which were available on the Internet as of 2018, we found the following (Table 2).

Table 2. Non-financial reporting of large enterprises

\begin{tabular}{|c|c|c|c|c|}
\hline $\begin{array}{l}\text { Position in } \\
\text { the ranking } \\
\text { of the top } \\
200(2016)\end{array}$ & Name of Company & The name of the report & $\begin{array}{l}\text { Reporting } \\
\text { period }\end{array}$ & $\begin{array}{l}\text { Reporting } \\
\text { standard }\end{array}$ \\
\hline 6 & LLC DTEK TRADING & $\begin{array}{l}\text { Integrated report } 2017 . \\
\text { Financial and non-financial } \\
\text { results. }\end{array}$ & 2017 & GRI, UN GC \\
\hline 10 & $\begin{array}{l}\text { SE “NAEK } \\
\text { "Energoatom" }\end{array}$ & Non-financial report & 2016 & GRI \\
\hline 24 & $\begin{array}{c}\text { PLLC METINVEST } \\
\text { B.V. }\end{array}$ & More than steel. Social report & $2015-2016$ & GRI \\
\hline 51 & $\begin{array}{l}\text { AH The Mironivsky } \\
\text { Hliboproduct }\end{array}$ & $\begin{array}{l}\text { Innovations for sustainable } \\
\text { development. Non-financial } \\
\text { report }\end{array}$ & 2017 & GRI \\
\hline 88 & SE NPC Ukrenergo & $\begin{array}{c}\text { The results of the first reforms. } \\
\text { Non-financial report }\end{array}$ & 2017 & GRI \\
\hline 141 & LLC ASTELIT & $\begin{array}{l}\text { Digital technologies of } \\
\text { humanity. Social report }\end{array}$ & 2017 & GRI, UN GC \\
\hline 146 & $\begin{array}{l}\text { FE Coca-Cola. } \\
\text { Beverages Ukraine } \\
\text { Limited }\end{array}$ & Social responsibility report & $2015-2017$ & Voluntary \\
\hline
\end{tabular}

Source: Own research

The most popular standard for nonfinancial reporting is GRI. In the framework of an arbitrary form of reporting, large enterprises mainly consider the UN Sustainable Development Goals as a structural factor.

However, we must emphasize that the available non-financial reports do not provide 
objective evidence of a holistic social responsibility management system. We found that the results presented in the reports are mainly the result of the implementation of quality management systems, environmental management and human resource management, and project management in terms of charitable, sponsorship and philanthropic activities of enterprises.

As we noted in the study, social responsibility, as a process of harmonizing stakeholders' interests, has a clear connection with the activities of any enterprise. Unfortunately, in the conditions of the crisis, most Ukrainian large enterprises do not realize the potential of social responsibility to the full. In our opinion, the factors influencing this situation are:

- lack of knowledge about models, mechanisms and standards of social responsibility;

- low capacity to attract additional resources;

- conscious selfish business development strategy;

- operation of the enterprise in the shadow or semi-shadow economy.

Based on the study results, we proposed and tested a new tool for assessing the transparency of social responsibility. This tool is of practical importance for developing a social responsibility strategy as an element of the national strategy for sustainable development. In the management of large enterprises, our method will provide additional data to assess the representation of achievements in social responsibility.

Based on the study results, we recommend that large companies fully and transparently cover their socially responsible activities. We also advise paying attention to the provisions of the SA8000 and ISO26000 standards, which contribute to social responsibility activities, improvement of the management system and transparency.

\section{References}

1. Aras, G., \& Crowther, D. (2009). Making sustainable development sustainable. Management Decision, 47(6), 975-

\section{This study has the following limitations.}

Methodical. The technique used is imperfect because it does not apply the tools of mathematical statistics. Its benefits are simplicity, economy and clarity.

Time and Location. We researched large Ukrainian enterprises in post-crisis conditions. The use of the methodology for enterprises in other countries and timelines can give different results.

Practical. Implementing transparency recommendations in enterprises will not make sense unless it is backed up by real action.

\section{CONCLUSION}

In this article, we explored the participation of large Ukrainian companies in achieving sustainable development goals by conducting and covering activities related to social responsibility. Based on the author's tool for assessing the transparency of social responsibility, we examined the data of several large leading companies in terms of profit and revenue. We found that in post-crisis conditions, the activity of enterprises to cover the results of social responsibility is low and not transparent enough. We found that information on the social responsibility of large enterprises in Ukraine is poorly structured, non-transparent and does not provide sufficient grounds for determining the degree of relationship between enterprises' level of social responsibility and the amount of their income or profit. We have recommended that large enterprises bring information about social responsibility activities they performed to a broader audience.

The obtained results serve as a guide for the development of a social responsibility strategy as an element of the national strategy for sustainable development and suitable for use in the management of large enterprises to improve the representation of achievements in the field of social responsibility.

988. https://doi.org/10.1108/0025174091096668

$\underline{6}$

2. Baraibar-Diez, E., \& Luna Sotorrío, L. (2018). The mediating effect of transparency in 
the relationship between corporate social responsibility and corporate reputation. Review of Business Management, 20(1), 521. https://doi.org/10.7819/rbgn.v20i1.3600

3. Bhullar, M. (2019). Investigating Corporate Social Responsibility Perceptions For Sustainable Development. Bioscience Biotechnology Research Communications, 12(3), 772778. https://doi.org/10.21786/bbrc/12.3/33

4. de Vries, B. J. M., \& Petersen, A. C. (2009). Conceptualizing sustainable development. Ecological Economics, 68(4), 10061019. https://doi.org/10.1016/j.ecolecon.2008.11 $\underline{.015}$

5. Dehghani Soltani, M., Shiri, A., Nesari, T., Raoufi, M. (2018). The Role of Social Media, Transparency and Social Responsibility in Promoting Business Performance of Travel and Tourism Services Companies. Tourism Management Studies, 13(43), https://doi.org/10.22054/tms.2018.9450

6. Gupta, J., \& Vegelin, C. (2016). Sustainable development goals and inclusive development. International Environmental Agreements: Politics, Law and Economics, 16(3), 433448. https://doi.org/10.1007/s10784-016-9323-Z

7. Halisçelik, E., \& Soytas, M. A. (2019). Sustainable development from millennium 2015 to Sustainable Development Goals 2030. Sustainable Development, 27(4), 545572. https://doi.org/10.1002/sd.1921

8. Hendijani Zadeh, M. (2020). The effect of corporate social responsibility transparency on corporate payout policies. International Journal of Managerial Finance. https://doi.org/10.1108/IJMF$\underline{07-2020-0386}$

9. Kang, J., \& Hustvedt, G. (2014). Building Trust Between Consumers and Corporations: The Role of Consumer Perceptions of Transparency and Social Responsibility. Journal of Business Ethics, 125(2), 253265. https://doi.org/10.1007/s10551-013-1916-7

10. Kolk, A., \& van Tulder, R. (2010). International business, corporate social responsibility and sustainable development. International Business Review, 19(2), 119125. https://doi.org/10.1016/i.ibusrev.2009.12.00 $\underline{3}$

11. Kolohoida, O., Lukach, I., \& Poiedynok, V. (2017). Legal Aspects of Corporate Social Responsibility in Ukraine on the Way to European Integration. Croatian Yearbook of European Law and Policy,
13(13). https://doi.org/10.3935/cyelp.13.2017.27 9

12. Lee, M., \& Kohler, J. (2010). Benchmarking and Transparency: Incentives for the Pharmaceutical Industry's Corporate Social Responsibility. Journal of Business Ethics, 95(4), 641658. https://doi.org/10.1007/s10551-010-0444-y

13. Lipych, L., Volynets, I., Khilukha, O., Matviichuk, I., \& Semchuk, Z. (2018). Model of management of the employees' innovative behavior at the industrial enterprises. Problems and Perspectives in Management, 16(3), $197-$ 206. https://doi.org/10.21511/ppm.16(3).2018.16

14. Mora Mayoral, M. J., \& Martínez Martínez, F. R. (2018). Desarrollo local sostenible, responsabilidad social corporativa y emprendimiento social. Equidad y Desarrollo, 31, 27-46. https://doi.org/10.19052/ed.4375

15. Mostenska, T., \& Bilan, Y. (2015). Sustainable development through enhanced social responsibility. Journal of Security and Sustainability Issues, 4(3), 552563. https://doi.org/10.9770/jssi.2015.4.3(4)S

16. Muñoz Pasadas, R., \& Tirado Valencia, P. (2014). Responsabilidad social y transparencia a través de la web: Un análisis aplicado a las cooperativas agroalimentarias españolas. REVESCO. Revista de Estudios Cooperativos, 114(0), 85-

105. https://doi.org/10.5209/rev REVE.2014.v1 $\underline{14.44293}$

17. Nair, R., Muttakin, M., Khan, A., Subramaniam, N., \& Somanath, V. S. (2019). Corporate social responsibility disclosure and financial transparency: Evidence from India. Pacific-Basin Finance Journal, 56, 330351. https://doi.org/10.1016/i.pacfin.2019.06.015

18. Our Participants. (2018, May 16). UN Global Compact. https: / / www.unglobalcompact.org/what-isgc/participants

19. Park, H., \& Ha, M. (2020). Corporate social responsibility and earnings transparency: Evidence from Korea. Corporate Social Responsibility and Environmental Management, 27(3), 14981508. https://doi.org/10.1002/csr.1922

20. Pejić Bach, M., Ante Omazić, M., \& Zoroja, J. (2015). Transparency as a Precondition of Systemic Behavior: The Case of European Retailing Banks Regarding Social Responsibility Communication: Transparency as a Precondition of Systemic Behavior. Systems Research and Behavioral Science, 32(2), 256264. https://doi.org/10.1002/sres.2267 
21. Raco, M. (2005). Sustainable Development, Rolled-out Neoliberalism and Sustainable Communities. Antipode, 37(2), 324$347 . \quad$ https://doi.org/10.1111/j.00664812.2005.00495.x

22. Tejedo Romero, F., Ferraz Esteves Araujo, \& Oaquim F. (2018). Transparency, Social Responsibility and Corporate Governance: Human Capital of companies. Cuadernos de Gestión, $18(2)$,

133-

162. https://doi.org/10.5295/cdg.160693ft

23. Vasconcelos, I. F. F. G. de, Alves, M. A., \& Pesqueux, Y. (2012). Responsabilidade social corporativa e desenvolvimento sustentável: Olhares habermasianos. Revista de Administração de Empresas, $52(2)$

148-
152. https://doi.org/10.1590/S0034$\underline{75902012000200002}$

24. Vasyltsiv, T., Lupak, R., \& Rudkovsky, O. (2019). Directions and means of improving social responsibility of enterprise in Ukraine. Ekonomika Ta Derzhava, 5, 4. https://doi.org/10.32702/2306-6806.2019.5.4

25. Watts, S. (2015). Corporate social responsibility reporting platforms: Enabling transparency for accountability. Information Technology and Management, 16(1), 1935. https://doi.org/10.1007/s10799-014-0192-2

26. Zinchenko A., Reznik N., \& Saprykina M. (2018). Transparency index of websites of Ukrainian companies. Yuston Publishing House. 